Огляди літератури, оригінальні дослідження, погляд на проблему, випадок з практики, короткі повідомлення УДК 616.06[616.085/616.36-004.4+616.37-002]

DOI 10.11603/1811-2471.2019.v.i3.10506

\title{
ОСОБЛИВОСТІ ПЕРЕБІГУ АЛКОГОЛЬНОГО ЦИРОЗУ ПЕЧІНКИ В ПОЄДНАННІ 3 ХРОНІЧНИМ ПАНКРЕАТИТОМ
}

\author{
๑О. Є. Самогальська, О. В. Шманько, Н. В. Лобанець \\ Тернопільський національний медичний університет імені І. Я. Горбачевського МОз України
}

\begin{abstract}
РЕзЮМЕ. На сьогодні алкоголізм, як причина смертності, посідає наступне місце після серцево-судинних захворювань і злоякісних утворень. Особливо страждають у результаті хронічної алкогольної інтоксикації печінка і підшлункова залоза, тому подальші дослідження особливостей поєднаної патології цих органів алкогольного походження є актуальними.

Мета - вивчити особливості поєднаного перебігу алкогольного цирозу печінки і хронічного панкреатиту з врахуванням змін в стані вільнорадикального окислення ліпідів і ендотоксемії.

Матеріал і методи. В дослідження було включено 166 хворих з АЦП, з них діагноз ХП був встановлений у 141. Середній вік хворих становив $(51,20 \pm 6,51)$ роки років, тривалість захворювання - $(2,8 \pm 1,8)$ роки.

Результати. При поєднаному перебігу алкогольного цирозу печінки і хронічного панкреатиту виявлено вірогідно більш значимі зміни в системі перекисного окиснення ліпідів і антиоксидантного захисту, виражений ендотоксикоз, підтверджено їх зв'язок з основними проявами цитолітичного і мезенхімально-запального синдрому.

Висновки. Поєднаний перебігу алкогольного цирозу печінки і хронічного панкреатиту сприяє посиленню цитолізу і запальному процесу, що сприяє процесам фібротизації печінкової тканини і прогресуванню змін тканини підшлункової залози.
\end{abstract}

КЛЮчОВІ СЛОВА: алкогольний цироз печінки, хронічний панкреатит, перекисне окиснення ліпідів, ендотоксикоз.

Вступ. На сьогодні алкоголізм, як причина смертності в усьому світі, посідає наступне місце після серцево-судинних захворювань і злоякісних утворень. Летальність від різних причин у осіб, які непомірно вживають алкоголь, у 2-3 рази вища, ніж у населення загалом. Універсальність впливу алкоголю на метаболізм, систему регуляції та морфологічних структур дозволяє стверджувати, що практично немає жодної системи або органа, які 6 не втягувалися у патологічний процес. Токсичні властивості етанолу пов'язані як з його безпосереднім місцевим впливом на слизові оболонки стравоходу, шлунка, кишечника, так і з системним впливом його метаболітів, особливо ацетальдегіду, що підвищує токсичність етанолу в 100 разів. Особливо страждають у результаті хронічної алкогольної інтоксикації органи-мішені: печінка, підшлункова залоза, шлунок, головний мозок, легені, серце нирки $[1,2]$. Дані світової статистики свідчать про зростання хворих на патологію печінки і підшлункової залози $[3,4]$. Одночасне ураження цих органів травлення спричиняє порушення асиміляції нутрієнтів внаслідок як первинної, так і вторинної зовнішньосекреторної недостатності підшлункової залози, формування якої пов'язано з порушенням емульгації жирів під впливом жовчних кислот, тому викликає інтерес вивчення поєднаної патології печінки і підшлункової залози. Уже проведені дослідження продемонстрували взаємообтяжувальний вплив на вираженість фіброзу при алкогольному ураженні печінки і підшлункової залози [5]. Тому подальші дослідження особливостей поєднаної патології органів травлення алкогольного походження $\epsilon$ актуальними.

Мета - вивчити особливості поєднаного перебігу алкогольного цирозу печінки (АЦП) і хронічного панкреатиту (ХП) з урахуванням змін в стані вільнорадикального окиснення ліпідів і ендотоксемії.

Матеріал і методи дослідження. В дослідження було включено 166 хворих з АЦП. Середній вік обстежених пацієнтів становив $(51,20 \pm$ 6,51 роки) років, тобто превалювали пацієнти працездатного віку, що підкреслює соціальне значення проблеми діагностики і лікування алкогольної хвороби печінки (АХП). Чоловіків було 130 (78,31\%), жінок - 36 (21,69 \%). Серед хворих на АХП переважали особи чоловічої статі, співвідношення кількості чоловіків до жінок становило 3,6:1, що пояснюється особливостями епідеміології АХП.

За анамнестичними даними тривалість захворювання хворих на алкогольну хворобу печінки (АХП) становила від 1 місяця до 14 років

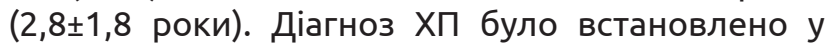
141 особи з 166, які були включені в основну, 1 групу, (ХП+АЦП), решта 25 пацієнтів увійшли в 2 групу (АЦП).

Алкогольну етіологію ураження підшлункової залози та печінки підтверджували за даними анамнезу життя і захворювання, спостереження у лікарів-наркологів, з використанням опитувальників CAGE, шкали Le Go. Діагноз захворювання 
Огляди літератури, оригінальні дослідження, поглядн на верифікували шляхом виявлення специфічних клінічних симптомів і синдромів, за результатами ультразвукового дослідження, даними комп'ютерної та магнітно-резонансної томографії органів черевної порожнини. Вивчення стану вільнорадикального окиснення ліпідів проводили за рівнем малонового діальдегіду (МДА) (за методом L. Placer), стан системи АОЗ оцінювали за вмістом ферментів - супероксиддисмутази (СОД) та каталази - у сироватці крові (за методикою Е. Е. Дубиніної і співавторів (1983), М. А. Королюк і співавторів). Показники ендогенної інтоксикації визначали за вмістом середніх молекул (СМ) у сироватці крові за методом Н. І. Габрієляна і співавторів, еритроцитарний індекс ендогенної інтоксикації (EIEI) - за методикою А. А. Тогайбаєва. Хворі з вірусним ЦП були включені в дослідження за умови відсутності маркерів активності вірусної інфекції. При наявності тяжкої супутньої патології або виражених ускладнень АЦП хворих у дослідження не включали. Статистичну обробку отриманих даних виконували на персональному комп'ютері за допомогою стандартних програм- роблему, випадок з практики, короткі повідомлення них пакетів Microsoft Excel і за допомогою комп'ютерної програми Statistica for Windows версії 10.0 (Stat Soft inc., США).

Результати й обговорення. В клінічній симптоматиці хворих обох груп превалювали астеновегетативний і диспепсичний синдроми з більшою вираженістю диспепсичного синдрому в групі 1 (р<0,05). У показниках гемограми спостерігали односпрямовані зміни з вірогідною різницею за рівнями гемоглобіну і еритроцитів, тобто схильністю до анемії, у хворих 1 групи. Рівні білірубіну, трансаміназ вірогідно перевищували нормативні в обох групах з вірогідною міжгруповою різницею ( $<0,05)$. Відмічалося більш значуще підвищення АСТ: в обох групах співвідношення (індекс де Рітіса) АСТ/Алт було більше 1, відповідно, 1,33 та 1,31, що вказує на некротичний характер цитолізу гепатоцитів.

Одним із основних механізмів токсичної дії метаболіту етанолу ацетальдегіду $є$ посилення процесів ПОЛ [1], тому важливим при АХПє дослідження змін системи перекисного окиснення ліпідів - антиоксидантного захисту (ПОЛ-АОЗ) (табл. 1).

Таблиця 1. Показники ПОЛ-АОЗ у обстежених хворих

\begin{tabular}{|l|c|c|c|}
\hline \multicolumn{1}{|c|}{ Показник } & ПзО, $\mathrm{n}=20$ & 1 група, $\mathrm{n=141}$ & 2 група, $\mathrm{n=25}$ \\
\hline МДА, мкмоль/л & $2,81 \pm 0,10$ & $6,49 \pm 0,14^{*}$ & $5,35 \pm 0,18^{*} / * *$ \\
\hline СОД, ум.од. & $60,44 \pm 3,43$ & $40,26 \pm 1,73^{*}$ & $36,85 \pm 0,98^{*}$ \\
\hline Каталаза, \% & $17,48 \pm 0,87$ & $31,95 \pm 0,86^{*}$ & $31,16 \pm 1,16^{*}$ \\
\hline ЦеП, мг/л & $645,60 \pm 2,60$ & $359,42 \pm 16,53^{*}$ & $358,17 \pm 15,18^{*}$ \\
\hline СН-групи, мколь/л & $60,50 \pm 2,13$ & $66,14 \pm 1,48^{*}$ & $75,02 \pm 1,75^{*} / *$ \\
\hline
\end{tabular}

Примітки: 1. * - різниця вірогідна порівняно з показником у П3О $(p<0,05)$;

2. ** - різниця вірогідна порівняно з показником у хворих 1 групи $(p<0,05)$.

Як свідчать дані, наведені в таблиці 1, в обох групах зареєстроване вірогідне зростання вмісту МДА в 1,9 раза $(p<0,05)$ і 2,32 раза $(p<0,05)$ відповідно. Найбільша інтенсивність ПОЛ виявлена при поєднанні АЦП і ХП (на 22,43 \% $(p<0,05)$ за рівнем МДА).

При вивченні показників АОЗ виявлено, що рівні показників другої лінії антиоксидантного захисту, антирадикального, СОД і ЦеП, виявилися нижчими, ніж у П30, на 34,34 \% (p<0,05) і 43,20\% $(p<0,05)$ відповідно. Рівень каталази - ферменту 3 антиперекисною функцією, був вірогідно підви- щений на 78,83 \% (p<0,05), цей факт можна пояснити компенсаторними реакціями організму у відповідь на автокаталітичне посилення процесів ПОЛ. У хворих обох груп вищезазначені зміни мали односпрямований характер, вірогідної міжгрупової різниці рівнів СОД, ЦеП і каталази при цьому не виявлено.

Хронічне зловживання алкоголем призводить до вираженого ендотоксикозу у хворих 3 АХП. Аналіз рівня маркерів ЕІ у хворих на АХП виявив вірогідні зміни всіх показників, що вивчалися (табл. 2).

Таблиця 2. Показники еритроцитарного індексу ендогенної інтоксикації у обстежених хворих

\begin{tabular}{|l|c|c|c|}
\hline \multicolumn{1}{|c|}{ Показник } & ПзО, $\mathrm{n}=20$ & 1 група, $\mathrm{n}=141$ & 2 група, $\mathrm{n}=25$ \\
\hline IEIE, \% & $27,25 \pm 1,22$ & $53,73 \pm 1,89^{*}$ & $40,82 \pm 1,44^{*} / * *$ \\
\hline CM-254, ум. Од. & $334,12 \pm 2,46$ & $540,06 \pm 1,21^{*}$ & $542,57 \pm 1,86^{*}$ \\
\hline СМ-280, ум. Од. & $147,50 \pm 1,23$ & $239,72 \pm 1,79^{*}$ & $251,18 \pm 1,76^{*}$ \\
\hline
\end{tabular}

Примітки: 1. * - різниця вірогідна у порівнянні з показником у ПзО $(p<0,05)$;

2. ** - різниця вірогідна у порівнянні з показником у хворих на 1 групи $(p<0,05)$. 
Огляди літератури, оригінальні дослідження, погляд на проблему, випадок з практики, короткі повідомлення

Рівень IEIE у хворих 1 і 2 груп вірогідно перевищував такий у П3О, відповідно в 1,5 і 2,0 рази $(p<0,05)$, різниця рівнів IEIE становила $31,58 \%$ $(p<0,05)$, що свідчить про поглиблення ендотоксемії у хворих із поєднаною патологією. Виявлено високий ступінь прямого лінійного зв'язку між рівнем МДА і IEIE $(r=0,770 ; p<0,05)$ при ЦП+ХП і низький - при ЦП $(\ulcorner=0,479 ; p<0,05)$, що підтверджує зв'язок процесів інтенсифікації ПОЛ і ендотоксикозу при розвитку АХП, особливо у випадках з поєднаною патологією.

Вивчення кореляційних зв'язків між маркерами El і основними проявами цитолітичного і мезенхімально-запального синдрому виявило

\section{ЛІТЕРАТУРА}

1. Алкогольная болезнь органов пищеварения / под ред. Н. Б. Губергриц, Н. В. Харченко. - К. : Новый друк, 2009. - 180 с.

2. Клінікогемодинамічні аспекти алкогольного цирозу печінки [Електронний ресурс] / О. Є. Самогальська, Н. В. Лобанець, А. М. Сидорівський, Л. Л. Куліковський // Сучасна гастроентерологія. - 2015. - № 2. C. 37-41. - Режим доступу: http://nbuv.gov.ua/UJRN/ SGastro_2015_2_7.

3. Löhr J. M. United European Gastroenterology evidence-based guidelines for the diagnosis and therapy of chronic pancreatitis (HaPanEU) / J. M. Löhr // United European Gastroenterology Journal. - 2017. - Vol. 5, Issue 2. P.153-199.DOI:http://doi.org/10.1177/2050640616684695

\section{REFERENCES}

1. Hubergritz, N.B., \& Kharchenko, N.V. (2009). Alkogolnaya bolezn organov pishchevarenya [Alcoholic disease of digestive organs]. Kyiv. Novyi druk [in Russian].

2. Samohalska, O.Ye., Lobanets, N.V., Sydorivskyi, A.M., \& Kulikovskyi, L.L. (2015). Klinikohemodynamichni aspekty alkoholnoho tsyrozu pechinky [Clinical and hemodynamical aspects of alcoholic liver cirrhosis]. Suchasna gastroenterolohiya - Modern Gastroenterology, (2), 37-41 [in Ukrainian].

3. Löhr, J.M. (2017). United European Gastroenterology evidence-based guidelines for the diagnosis and therapy of chronic pancreatitis (HaPanEU). United European Gastroenterology Journal, 5 (2), 153-199. високий ступінь прямого лінійного зв'язку між рівнями IEIE і АЛТ $(r=0,892 ; p<0,05)$, IEIE i АCT $(r=0,765 ; p<0,05)$, рівнями IEIE і білірубіну $(r=0,704$; p<0,05) у пацієнтів 1 групи, і низький при ЦП.

Висновки. При поєднаному перебігу АЦП і ХП глибина ендотоксикозу і пов'язана з нею значна інтенсифікація ПОЛ призводить до посилення цитолізу і запального процесу, що сприяє процесам фібротизації печінкової тканини і прогресуванню змін тканини підшлункової залози.

Перспективи подальших досліджень полягають у розробці ефективних методів профілактики прогресування хронічного панкреатиту та фіброзу печінкової тканини.

4. Capurso G. Prevalence of chronic pancreatitis: Results of a primary care physician-based population study / Capurso G. // Digestive and Liver Disease. - 2017. - Vol. 49, Issue 5. - P. 535-539. DOI: http://doi.org/10.1016/j. dld.2016.12.024

5. Міщук В. Г. Рівень колагену IV типу і непрямих маркерів фіброзу у хворих з поєднанням хронічного алкогольного панкреатиту та цирозу печінки класу А та В за класифікацією Чайльда-П'ю [Електронний ресурс] / В. Г. Міщук, К. М. Скоропад // Сучасна гастроентерологія. - 2015. - № 3. - С. 15-21. - Режим доступу: http:// nbuv.gov.ua/UJRN/SGastro_2015_3_4.

4. Capurso, G. (2017). Prevalence of chronic pancreatitis: Results of a primary care physician-based population study. Digestive and Liver Disease, 49 (5), 535-539.

5. Mishchuk, V.H., \& Skoropad, K.M. (2015). Riven kolahenu IV typu i nepriamykh markeriv fibrozu u khvorykh z poiednanniam khronichnoho alkoholnoho pankreatytu ta tsyrozu pechinky klasu A ta B za klasyfikatsiieiu ChaildaPiu [The levels of collagen type IV and indirect markers of fibrosis in patients with comorbid chronic alcoholic pancreatitis and liver cirrhosis of class A and B by Child-Pugh score]. Suchasna hastroenterolohiia-Modern Gastroenterology, (3), 15-21 [in Ukrainian].

\title{
ОСОБЕННОСТИ ТЕЧЕНИЯ АЛКОГОЛЬНОГО ЦИРРОЗА ПЕЧЕНИ В СОЧЕТАНИИ С ХРОНИЧЕСКИМ ПАНКРЕАТИТОМ
}

\author{
ОЕ. Е. Самогальская, О. В. Шманько, Н. В. Лобанец
}

Тернопольский национальный медицинский университет имени И. Я. Горбачевского МОз Украины

РЕзЮмЕ. Сегодня алкоголизм, как причина смертности, находится на следующем месте после сердечнососудистых заболеваний и злокачественных новообразований. Особенно страдают в результате хронической алкогольной интоксикации печень и поджелудочная железа, поэтому дальнейшие исследования особенностей сочетанной патологии этих органов алкогольного происхождения являются актуальными. 
Огляди літератури, оригінальні дослідження, погляд на проблему, випадок з практики, короткі повідомлення

Цель - изучить особенности сочетанного течения алкогольного цирроза печени и хронического панкреатита с учетом изменений в состоянии свободнорадикального окисления липидов и эндотоксемии.

Материал и методы. В исследование было включено 166 больных с алкогольным циррозом печени, из них диагноз хронического панкреатита был установлен у 141. Средний возраст больных составил $(51,20 \pm 6,51)$ лет, длительность заболевания - $(2,8 \pm 1,8)$ года.

Результаты. При совместном течении алкогольного цирроза печени и хронического панкреатита выявлены достоверно более значимые изменения в системе перекисного окисления липидов и антиоксидантной защиты, выраженный эндотоксикоз, подтверждена их связь с основными проявлениями цитолитического и мезенхимально-воспалительного синдрома.

Выводы. Совместное течения алкогольного цирроза печени и хронического панкреатита способствует усилению цитолиза и воспалительного процесса, что стимулирует процессы фибротизации печеночной ткани и прогрессирование изменений ткани поджелудочной железы.

КЛЮЧЕВЫЕ СЛОВА: алкогольный цирроз печени; хронический панкреатит; перекисное окисление липидов; эндотоксикоз.

\title{
FEATURES OF THE COURSE OF ALCOHOLIC LIVER CIRRHOSIS COMORBID WITH CHRONIC PANCREATITIS
}

\author{
๑O. Y. Samohalska, O. V. Shmanko, N. V. Lobanets \\ I. Horbachevsky Ternopil National Medical University
}

SUMMARY. Today, alcoholism, as the cause of mortality, is on the next place after cardiovascular diseases and malignant neoplasms. The liver and pancreas are especially affected as a result of chronic alcohol intoxication, so further studies of the characteristics of the combined alcoholic pathology of these organs are relevant.

The aim of the study - to learn the features of the combined course of alcoholic liver cirrhosis and chronic pancreatitis, taking into account changes in the state of free radical oxidation of lipids and endotoxemia.

Materials and Methods. The study included 166 patients with alcoholic liver cirrhosis, 141 of whom were diagnosed with chronic pancreatitis. The average age of the patients was $(51.20 \pm 6.51)$ years, the duration of the disease was $(2.8 \pm 1.8)$ years.

Results and Discussion. With the comorbid course of alcoholic liver cirrhosis and chronic pancreatitis, significant changes in the lipid peroxidation and antioxidant defense systems, and a pronounced endotoxicosis were revealed, their relationship with the main manifestations of cytolytic and mesenchymal inflammatory syndrome was confirmed.

Conclusions. The comorbid course of alcoholic liver cirrhosis and chronic pancreatitis enhances cytolysis and the inflammatory process, which in turn stimulates the processes of fibrotization of the liver tissue and the progression of pathological changes in the pancreatic tissue.

KEY WORDS: alcoholic liver cirrhosis; chronic pancreatitis; lipid peroxidation; endotoxicosis.

Отримано 14.09.2019 